\title{
iZindaba Zokudla: A conversation about food systems change in South Africa
}

\author{
Naudé Malan* \\ University of Johannesburg
}

Submitted March 12, 2019 / Revised May 22, September 28, and October 8, 2019, and June 3

and July 10, 2020 / Accepted July 10, 2020 / Published online October 14, 2020

Citation: Malan, N. (2020). iZindaba Zokudla: A conversation about food systems change in South Africa. Journal of Agriculture, Food Systems, and Community Development, 10(1), 29-42.

https://doi.org/10.5304/jafscd.2020.101.016

Copyright (C) 2020 by the Author. Published by the Lyson Center for Civic Agriculture and Food Systems. Open access under CC-BY license.

\begin{abstract}
iZindaba Zokudla (IZ) is a multistakeholder engagement project that aims to create opportunities for urban agriculture in a sustainable food system in Johannesburg. IZ implements the Farmers' Lab, a social lab used as a transitional mechanism in a larger transition to sustainability. To move the South African urban food system to an ecologically sound, economically productive, and socially equitable system, significant stakeholder integration is needed, and the iZindaba Zokudla Farmers' Lab provides that. This reflective essay presents a history of the project (2013 until now) detailing the project's creation of an ecosystem based on social labs that facilitate innovation in the food system. Emergent entrepreneurs and others use the social labs and their activities, as well as stakeholder engagement in their enterprise development, and these Labs have created opportunities
\end{abstract}

* Naudé Malan, Senior Lecturer in Development Studies, Department of Anthropology and Development Studies, University of Johannesburg; convener of iZindaba Zokudla; nmalan@uj.ac.za for applied and other research in the university. This has brought innovation and change to agroecological practice in Johannesburg. This reflective essay article situates IZ within the broader evolutionary change in South Africa and considers how conversations about food lead to the creation of sustainable food systems.

\section{Keywords}

Multistakeholder Engagement, Social Labs, Urban Agriculture, Social Innovation, Entrepreneurship, Food Systems, Transitions to Sustainability

\section{Introduction: iZindaba Zokudla and South Africa's Food System}

In 2013 I held a three-day workshop in Soweto with my colleague Angus Campbell from the University of Johannesburg. We developed a strategic plan for the development of urban agriculture in Soweto, as part of a participatory technology development service-learning project (Campbell \& Malan, 2018; Malan, 2020a; Malan \& Campbell, 2014). This eventually became known as the iZindaba Zokudla - Conversations about Food 
Farmers' $L a b$. The name invokes the idea of community deliberation about food through an "iZindaba" (the traditional court of the king) about "Zokudla," (the food that we eat). iZindaba Zokudla (hereafter IZ) organizes the Farmers' Lab, which has set in motion a number of changes in the Johannesburg food system. This essay reflects on how this has happened.

Multistakeholder engagement methods developed by the NGO TransForum (Regeer, Mager, \& van Oorsouw, 2011; Van Latesteijn \& Andeweg, 2011) and REOS Partners (REOS Partners \& TransForum, 2011) lie behind the Lab. The Lab allows emergent producers to draw on resources from the University of Johannesburg, such as the UJ's Process, Energy, Environment, and Technology station (UJ-PEETS) ${ }^{1}$ and the UJ Centre for Entrepreneurship ${ }^{2}$ (UJCfE) and its forum: Let's Talk Business. ${ }^{3}$ The Johannesburg Chamber of Commerce and Industry ${ }^{4}$ — an important mainstream stakeholder-has collaborated with IZ to develop a focus on emergent farmers and entrepreneurs. This essay considers how these shifts occurred in the South African food system.

The monthly $L a b$ is widely advertised and attracts between 100 and 400 urban farmers and related stakeholders. Due to the apartheid history of South Africa, these farmers and stakeholders are considered emergent, or new, participants in the economy who struggle to establish viable enterprises in the food system. A "social lab" (Hassan, 2014a, 2014b; Kahane, 2010) can bring such actors into the food system by using multistakeholder engagement methodology (Dubbelling, 2010; Regeer et al., 2011; Southern Africa Food Lab [SAFL], 2015; UN Habitat, 2008; Van Latesteijn \& Andeweg, 2011) and participatory design methodologies (Manzini, 2014). The monthly Lab echoes ideas about food policy councils (see Ledger, 2016) and local traditions of community meetings. The European idea of a living lab (Dutilleul, Birrer, \& Mensink, 2010; McGann, Blomkamp, \& Lewis, 2018; McGann, Wells, \& Blomkamp, 2019) is similar to what IZ has created, albeit located outside the state in civil society. With this Lab, I created a unique opportunity to experiment with interactions between the university and society and attempt innovation in the food system. Along with the stakeholders, I have gained important experience on how contemporary actors attempt to change food systems.

The $L a b$ is situated in a classical "mercantileindustrial food regime” (McMichael, 2009, p. 143) dominated by a large retail sector (Ledger, 2016) with a sizeable informal sector (Battersby, 2011). Large rural commercial producers dominate agriculture in South Africa (Greenberg, 2010), and they are, as is the case elsewhere, under pressure to transform (Blattner 2020; IPES-Food, 2016; McIntyre, Herren, Wakhungu, \& Watson, 2009; NASEM, 2018; Pereira, Karpouzoglou, Doshi, \& Frantzeskaki, 2015). South African agriculture is racialized and divided between white commercial agriculture and black emergent and small-scale agriculture. State programs (Broad-Based Black Economic Empowerment Act No. 25899, 2004; Codes of Good Practice on Broad Based Black Economic Empowerment No. 1354, 2017), including land reform, point to racially affirmative targets and outcomes. Unfortunately, " $90 \%$ of [these] redistributed farms are not productive" (The Economist, 2015, pp. 40-41), and only "around 50 percent have improved ... livelihoods" (Cousins, 2018, p. 7). Transformation, in general, has to build a "class" of African food producers in a context where they have been systematically marginalized or "depeasantized" (Bundy, 1988; McMichael, 2005). The $L a b$ in this dualistic agricultural structure (Cochet, Anseeuw, \& Fréguin-Gresh, 2015) nevertheless aims to create opportunities for urban agriculture in a sustainable food system.

Urbanization (Frayne, Crush, \& McLachlan, 2014), capital influx, and modern mall and supermarket development place an emerging South African township entrepreneur in a peculiar position where there is "little chance of ... finding a footing

\footnotetext{
1 https://www.uj.ac.za/faculties/febe/peets

2 https://www.uj.ac.za/faculties/cbe/ujcfe

3 https://www.facebook.com/talkbusinessjohannesburg/

${ }^{4}$ http://www.jcci.co.za/cms/index.php?command=View\&item id=192
} 
in a high-end commercial space to sell his wares" (Mahajan, 2014, p. 2). Townships were and are labor repositories isolated from economic centers and served as key instruments of oppression under apartheid. For urban farmers, these modern mall and supermarket developments can be seen as the urban part of an "adverse incorporation" (Neves \& du Toit, 2014, p. 846) into a neoliberal global food system. This may explain why urban agriculture delivers only minor benefits for farmers in South Africa (see Crush \& Frayne, 2011; Frayne, McCordic \& Shilomboleni, 2014; Ruysenaar, 2013), which is unsurprising (Stewart et al., 2013; Zezza \& Tasciotti, 2010), but debatable (Csortan, Ward, \& Roetman, 2020; Diekmann, Gray, \& Baker, 2018; Dubbelling, 2010; Nkosi, Gumbo, Kroll, \& Rudolph, 2014; UN Habitat, 2008). IZ has pioneered methods, events, and processes, albeit peculiar to the immediate context, to enable African and other marginalized producers (like urban farmers and emerging food processors) to gain access to various entry points in the South African food system. This reflective essay addresses a number of key questions for understanding such a transformative approach.

\section{What Does iZindaba Zokudla Do?}

IZ hosts, among other events, the Farmers' Lab at the Soweto Campus of the University of Johannesburg. This open, facilitated event invites emerging farmers and entrepreneurs, state officials, businesses, and activists to introduce new opportunities, technology, services, products, and systems for emerging entrepreneurs and activists. The Khula! app available on Google Play, and the aparate.co system, were launched in the Lab. IZ has influenced submissions to parliament (Rousell, 2017), established seed libraries (Slow Food, 2018), and organized (with the NGO Slow Food) the Soweto Eat-In (since 2016) that showcases the best in heritage, sustainable, and indigenous foods. The $L a b$ is an omnibus event that has been able to create "innovative governance arrangements that cross multiple geographic, scalar, and administrative boundaries" (Hammelman et al., 2020, p. 72).

The $L a b$ is a transitional mechanism in the broader transition to sustainability in South Africa. Innovation is "a complex, multifaceted and dynamic process involving multiple and changing stakeholders, interacting intimately with its environment, evolving over long periods and unfolding in directions impossible to devise from the start" (Triomphe et al., 2014, p. 54). A social lab recreates the conditions for such innovation to occur as it offers an opportunity for "a sequence of technological and organizational innovations ... to take root and [offer] improved opportunities for local communities" (Triomphe et al., 2014, p. 49). IZ and the Farmers' Lab have enabled innovation in the Johannesburg food system in the form of publications and opportunities for structured and unstructured interaction. They have also anchored and built relationships between academia, businesses, and stakeholders (Hammelman et al., 2020, p. 80-82). Recalling the history of the project, and the Slow Food Soweto Eat-In, enables a deep understanding of the key themes and concerns in such transitions to a more sustainable food system. I now turn to a discussion of the leading themes underlying a transition to sustainability in order to show how they can be utilized as a means to effect change in the food system.

\section{iZindaba Zokudla and Transitions to Sustainability}

\section{Transformation after Apartheid}

A sustainable food system in South Africa firstly implies a de-racialized economy with increased participation by previously marginalized (mostly African) entrepreneurs. The next step includes sustainability in their enterprises by adopting sustainable (ecological, social, and economic) production methods, such as appropriate technology and circular economy business models, and the delivery of sustainable products that have low ecological impacts and equitable redistribution. A true achievement of a sustainable food system would result from the networks, synergies, and interactions among actors and stakeholders in the system. The emergence of innovative enterprises that deliver social benefit and transformation goals is certainly due to evolutionary drivers in South African society that emphasize de-racialization, smallfarmer development, and township revitalization (Cochet et al., 2015). These innovative enterprises 
are also a background driver of an evolutionary transition in South Africa (Friedmann \& McMichael, 1989; Geels \& Schot 2007). As the facilitator, I had the opportunity to strategically interpret emerging farmer development as a problem of entrepreneurship and deliberately enabled coalitions among stakeholders to focus on it. This implies methodological, associative, and narrative dimensions, and below I show how these are valuable in a transition to sustainability.

Small farmers need to be "entangled" with stakeholders (Latour, 2007, pp. 84, 136) to shape an inclusive transition (Garud \& Gehman, 2012; Pereira, Drimie, Maciejewski, Tonissen, \& Biggs, 2020). Within this evolutionary context, associations, networks, social capital as a relational driver, and narratives and stories about the past and future as durational drivers (Coenen, Benneworth, \& Truffer, 2012), play a role. Transitions show interactions among associations, innovations, and actors, narratives of change, and the political economy (Pereira et al., 2020).

\section{Facilitation and Methods as Means to Food Systems Change}

Facilitative methods that allow for diverse crosssociety interaction aim to create interpersonal change (Bojer, Roehl, Knuth, \& Magner, 2008; Kahane, 2010; Regeer et al., 2011) through meeting "the other." This is necessary for meaningful innovation in a divided society. Participation starts when we shift from thinking, "someone should" to "I will," as this enables "actors to ... undertake individual and collective actions ... to shift the system" (Kahane, 2010, pp. 118, 125). Facilitation and events enable people's agency to influence deeper processes (Nogueira et al., 2020). Cross-society interaction can subvert differences among people (Anderson \& McLachlan, 2015) and build "bridges" between knowledge systems by "layering" different kinds of knowledge and interests alongside each other. As a result, new activities, narratives, and a "transmedia" emerge that make scientific and other meanings accessible. Facilitative methods create social "raw material" that entrepreneurs use to create their enterprises, and these embody a further transition to a sustainable system (Lynde, 2020; Malan, 2020b; Tobias, Mair,
\& Barbosa-Leiker, 2013). Below I discuss how the facilitation of the Farmers' Lab makes such systemic innovation possible.

\section{Creating Stories of Change}

Methods build networks, associations, and communities, and enable us, providing a safe space (Bennet et al., 2016; Kahane, 2010; Pereira et al., 2015) to reconstruct and narrate the past, present, and future. Narratives are important for the generational nature of sustainable development, as anything can be recycled as narrative, from geography, to opportunities, to technologies, and synergies among systems and enterprises become possible through our stories. A narrative about sustainability thus has technical benefits because a narrative can show how new technical information can be used and re-used. I show this by reflecting on the Slow Food Soweto Eat-In and how such narratives have shaped the activities of IZ and how entrepreneurs create their enterprises.

\section{Building Networks and Narratives}

A "safe space" allows actors to "support diverse, autocatalytic networks of human agents that can propel transformation toward goals such as sustainable energy" or food (Lenton \& Latour 2018, p. 1067). The emergence of autocatalytic or selforganizing networks among stakeholders and actors results from evolutionary shifts, narratives, and methods, but primarily from the associative behavior of actors. Social change lies outside the capability of a single actor but is possible in the form of a "cascade" of changes that emerges when actors and actions enable others to act (Latour, 2007).

These cross-society networks can be described in terms of social capital (Herbel \& Haddad, 2012; Malan, 2015), networks and power (Castells, 2009) and how actors can use objects and persons in their strategic activities — often through narratives that "animate" an "autocatalytic" network or community. Bonding social capital among similar actors is necessary for both an emergent African class of producers to emerge collectively and for a territorial or local focus to become visible. However, the need for systemic innovation, and to break local parochialism, requires a form of bridging social capital among dissimilar actors, and, here, examples 
of cross-sector and society linkages are offered that utilize narratives and other cues to build such networks (that, in turn, can lead to the formation of enterprises).

Narratives allow an actor to sequence social capital, technology, networks, and stakeholders, among other things, as part of enterprise development and an evolutionary shift in society. However, great systemic change will emerge if we can form bonds among highly diverse actors that link local actors with globally significant issues and stakeholders. Linking social capital unifies broader forces in society. To understand this, I offer dense descriptions that show how narratives and actions, events, stakeholders, and other cues can motivate networks, sectors, and entire economies and societies to move in a particular direction. I then reflect on how such grand change can be attempted from a local vantage point.

This approach to social change is consistent with practitioners who advocate for simultaneous change in many places in the system (Burns, 2012, 2014) and the "polycentric" governance (Ruysenaar, 2013; Pereira \& Drimie, 2016) of transitions. Such approaches can accommodate inclusion and experimentation (Bennett et al., 2015), continuous learning and scaling (Pereira et al., 2015), and disrupt existing paths of practice (Jørgensen, 2012; Regeer et al., 2011). To make sense of this, I reflect on how background political evolutionary drivers in IZ create opportunities for a transition, how methodological interventions make a difference, and why associations are important in utilizing stories of the past, present, and future to enable shifts to sustainability.

The Soweto Eat-In may be a singular case of change (Yin, 2009) that emphasizes how emerging farmers can build cross-society linkages. The broader history of IZ allows me to show how narratives and general activities can be utilized in building coalitions of actors across social divides.

\section{Sources of Knowledge and the Organization of the Case Study}

There has been very little original material pub- lished on IZ. The Facebook page ${ }^{5}$ and website ${ }^{6}$ are true but very partial reflections of the events and activities the project undertakes. This article draws on my experiences as the convener of IZ, my field notes, occasional interviews, and numerous conversations to present a short chronological and thematic history of this project. I have kept detailed records of the project. Publicly visible social media, open discussions during the events the project hosts, semiconfidential information on social media, and my confidential field notes inform the case study. As both an academic and an activist, I can offer a grounded description of the project, albeit with a complex of different kinds of public and confidential information. The article does not offer objective empirical knowledge, but rather an insiders' (and mild) activist perspective on the events and activities of the project. It is aimed at practical enlightenment and theoretical reflection. Because it is impossible to obtain direct consent from all respondents (some gave it in the context of a confidential interview), this article is ethnographic in character. It tries to abstract the knowledge gained and may, at times, conceal identities as it aims firstly to deliberate on abstract issues in the food system. However, given that most of the activities presented here were made in public, I unavoidably refer to some organizations and individuals in an identifiable way.

\section{A History of iZindaba Zokudla}

Our initial 2013 workshops created a strategic plan for urban agriculture in Soweto. The workshops aimed to embed the initial service-learning activities in a broader context. I conducted four months of prior fieldwork to enable a contextual understanding of the area and to mobilize stakeholders for the workshops. This strategic plan, created using a variation of open space methodology and a SWOT analysis done by a local, organic intellectual, identified key focus areas for urban agricultural development. This plan presents a crucial picture of what needs to change to support urban agriculture in Soweto. The plan emphasized eight key focus areas for change:

5 https://www.facebook.com/IzindabaZokudla/

${ }^{6}$ https://izindabazokudla.com 
1. Land and Water (Soil);

2. Relevant Stakeholders (Authorities, Extension Officers);

3. Training (Youth, Skills, Information);

4. Tools (Greenhouse, Tractor, Technology, Infrastructure);

5. Marketing (Transport, Business development, Agro-processing);

6. Organizational Development (Cooperatives, Labor);

7. Permaculture (Pests, Seeds, Composting); and

8. Security (Theft, Fencing).

The third focus area (training) was, in fact, on some posters in the workshop presented as a farmers' school - the initial name for the Farmers' Lab. The reference to permaculture is an important marker of the desirability of a biologically based agriculture, but also of the economic, political, and other choices farmers want to make as they farm.

These workshops triggered a proliferation of unplanned activities when a few invited academics came on the wrong day. Christa van Zyl (2014) developed participatory design methods for graphic design, and Joyce Sibeko established a relationship between iZindaba Zokudla and the UJ Centre for Entrepreneurship. These shifts in the university fortuitously linked IZ to its current entrepreneurial focus. Ancillary and unplanned activities parallel to mainstream interventions do emerge from social labs as actors use such workshops for their own projects (Nogueira et al., 2020). This pluralizes activities and creates alternative avenues of action for participants that are important in safeguarding the autonomy of actors and stakeholders.

Angus Campbell and I implemented the participatory technology development service-learning courses in 2014 (Campbell \& Malan, 2018; Malan, 2020a; Malan \& Campbell, 2014), and I held four additional workshops with educators on school gardens. The School Garden Dialogues aimed to persuade schools to combine agriculture and entrepreneurship. Unfortunately, this was abandoned after participation by teachers dwindled, and in the first interview that took place in April 2015, officials mentioned the difficulties of breaking the silos in the then Department of Education. However, many of these educators and farmers are still regulars at the Farmers' Lab.

The Farmers' Lab, the key event in IZ, emerged after it became clear that the participatory technology development service-learning course could not continue due to the difficulty of coordinating humanities and design students' schedules, although students found the activities very enriching (Campbell \& Malan, 2018; Malan, 2020a). Participatory and intermediate technology design nevertheless became part of Angus Campbell's research program, albeit implemented at the master's level (Brand, 2014; Brown, 2017; Harrison, 2017). The program offers clear lessons on how we can design for progressive outcomes (Campbell, 2017; Campbell \& Brown, 2018; Campbell \& Harrison, 2015).

The Lab emerged almost by accident after a nearby institution offered to teach informal agriculture courses at the Lab but withdrew at the last minute. A local farmer, certified as a master permaculture trainer, stood in to teach for half a day at each $L a b$. This gave birth to the idea to use local farmers to lecture on important topics in the Lab. As a pleasant side effect, this structure also helped us realize how to enhance the density and number of relationships among farmers and entrepreneurs. From these beginnings, the current format of the Labs that combines local and outside experts emerged iteratively by trial and error, as well as through theoretical reflection on the needs of systemic change.

The Lab, hosted once a month and up to 10 times a year (as opposed to twice a month in 2015/16), attracts numerous stakeholders, as was the case with Slow Food. This NGO endeavors to empower emergent farmers to protect traditional, heritage, and other foods, by helping them overcome cost barriers. Subsequently, the Lab significantly lowers the opportunity cost for businesses, activists, and the state to interact with such emergent entrepreneurs. The Lab allows stakeholders and actors to develop projects, networks, and relationships among themselves, and this has implications for systemic change. These events organize and re-organize stakeholders, keep them updated, solicit additional participation, and make available ample information and goodwill to implement 
interventions. The $L a b$ is utilized as a safe space, which lowers the cost of autonomous action, as ideas can be pitched in the $L a b$ before costly realworld implementation.

\section{Daily Program}

The $L a b$ is a rowdy affair with anywhere from 100 to 400 participants arriving for the day. Participants include farmers and food processors, students volunteering time at the $L a b$, entrepreneurs (who are often looking for products or clients), stakeholders to change, and the occasional surprise visitor. Farmers bring produce to sell at the Lab, and there have even been attempts to institute some farmers markets at the events. This rowdy plurality of participants provides the raw material needed for innovative practices and forms the basis of further action. Reflection on the daily program enables deeper methodological understanding.

The daily program is controlled by an agenda inclusive of the theme of the day, which is announced on the media. The themes are often determined in an end-of-year evaluation and planning session. As the facilitator, I also deliver a formal editorial, which sets the theme for the day. Anyone can make an announcement in the subsequent announcements hour, and these are captured through photos and video. Details of the opportunity are written down on the blackboard, posted on Facebook and aparate.co pages, and also typed up in a report published on Facebook. This leaves a digital record of the project, which enables any participant to retrieve details of the event and network at any time. This is followed by an expert-tofarmer and farmer-to-farmer lecture, often on the same topic and presented in a vernacular language that enables immediate understanding of complex topics like technology or new services.

Each event is further documented through an attendance register, an SMS notification system, a sign-up sheet for farmers to be allocated a formal slot in next week's proceedings, other documentation that a stakeholder might need, and a declaration of ethics for the event. This enables the development of the next event's agenda and enables record-keeping and advertising. The documents on the activities of each day - the editorial, a report on the day, and ad hoc documentation-leave a trace for further study as everything is posted on Facebook and aparate.co. This creates a plurality of records for each event that anyone can use to organize themselves or others. This proto-digital participatory project management system (Malan \& van der Walt, 2019) led to the development of IZ's website $^{7}$ by Juanita van der Walt.

\section{Yearly Program}

The daily program of the $L a b$ runs parallel to a yearly program that is developed at the beginning or end of each year using variations of Open Space and World Café in an evaluation and planning exercise. This is difficult to follow due to inconsistent presenters but gives participants control over the proceedings. Participatory methods that need time and focus stand in some tension with the plurality of the event. Specific issues, however, can be attended to in the Lab, as the African Centre for Biodiversity (ACBIO) did when they workshopped seed libraries and their submission to parliament in August 2017. The agenda changes often depending on which stakeholders participate on a particular day, but the events nevertheless enable structured engagement. Independent retailers, for instance, have used the Lab to build competitive supply chains that recruit farmers by declaring the percentage of shelf prices that will be paid to them. This makes them accountable in public and, in fact, governs the food system. Those who aim to host similar events could develop a yearly program along production cycles and perennial themes, say, for a producer group. The Lab, however, is best for pluralizing such a program as alternative actors will surely emerge, and this can lead to great dynamism among stakeholders, given that a single stakeholder cannot capture a group of farmers. Participants can also control how stakeholders may gain access to them.

The $L a b$ serves as a meeting place and opportunity for singular actors to expand their reach by making use of the material in the Lab for their own enterprise development. Broader movements have emerged, like an iZindaba Zokudla forum in

${ }^{7}$ https://www.izindabazokudla.com/ 
another city with a companion page on Facebook. ${ }^{8}$ The $L a b$ reduces risks and costs of enterprise development and elicits specialist support from a broad coalition of stakeholders as information and opportunities, technologies, and services are offered. It enables both stakeholders and entrepreneurs to renegotiate standard and blueprint ideas on agricultural and enterprise development. This is where innovation lies: in the interactions among peers in a public space.

Such innovation emerges from the program of the $L a b$ : The first announcement made in the $L a b$ was by a local chicken-feed maker who sought and immediately started trading with local chicken farmers. These announcements are used regularly by UJ-PEETS, UJCfE, and activists to recruit stakeholders. Some entrepreneurs use the hour to market their business, and many use it to gauge client reactions to new products. The Lab hosts movie screenings, has organized ancillary activities like a gardens tour in Soweto for farmers, and has facilitated the planning for a greater event, the Slow Food Soweto Eat-In. This has enabled a broad ecosystem wherein actors and stakeholders can operate and has resulted in interesting developments in the food system in Soweto, Johannesburg. However, the building of formations with and beyond social capital connections is what is most interesting of IZ. To understand this, it is necessary to reflect on the Slow Food Soweto Eat-Ins, as these bring together a greater cross-section of stakeholders to food systems change in South Africa.

\section{The Slow Food Soweto Eat-In}

The Soweto Eat-In (2016, 2017, and 2018) is a key institutional opportunity that has catalyzed a cascade of additional changes by bringing together a diversity of actors in the food system. An "eat-in" is a European tradition of gathering in the village square for a communal meal. Slow Food Johannesburg and the South African Chef's Association had been hosting eat-ins at various wealthy country clubs and resorts. However, they had a more compelling interest in hosting an event in a South African Township. The series of events that led to the creation of the Soweto Eat-in illustrates how a cascade of changes can emerge in a food system.

The Lab hosted a Food Processing Day in April 2016 with lectures from both chefs and local caterers. Caroline McCann, a representative of Slow Food International, suggested that we incorporate local caterers in the planned Eat-In. The Lab on the day could further organize farmers for a farmers market at the Eat-In. This allowed me to further innovate, and I suggested creating a Free People's Conference, which brought public dialogue and significant new stakeholders, such as a local chapter of the FAO, to the event. This cascade of features was built upon the current Slow Food and the South African Chefs Association's cooking competition and led to a multifaceted event.

The Free People's Conference at the Soweto Eat-In was an open and free conference that facilitated dialogue about the food system among diverse stakeholders, experts, and laypersons through panel discussions on a range of topics. This conference, nested in the greater event and slogan of "good, clean and fair" food (Slow Food, 2018), creates narratives, product profiles, and enterprise models for emerging entrepreneurs. The South African Chefs Association's cooking competition utilized a free-range, grass-fed Nguni cow (an indigenous breed) that emphasized sustainable eating. This eventually included the Skaftini (lunchbox) challenge that emphasized a healthy lunchbox for the National School Nutrition Program. This layered yet another meaning onto the event. A Farmers' $L a b$ team competed in this challenge in 2016, which led to Slow Food sponsoring them on an entrepreneurship course. All of these chefs subsequently established new enterprises.

The Eat-In as an event highlights the effectiveness of a networked and locally based strategy for change. I mentioned in my notes that we could piggyback on the larger organizational capabilities of Slow Food for this event, as Slow Food did with IZ to reach emerging farmers. This opportunity to build two-way, mutually beneficial networks led to a cascade of innovations that radically differentiated the Eat-Ins from their European counterparts.

${ }^{8}$ https://www.facebook.com/IzindabaZokudlaPage/ 
This enabled all stakeholders, particularly emerging and new ones, to achieve more than they themselves could do on their own. This integration of interests was how the event became possible and brought together not only the author, but also newer stakeholders, like the South African Chefs Association, and the wider university. The Seven Colors Market that commenced immediately after the Eat-In on the same site boosted the network and local character of the event even further. This fortuitously linked food as a theme to a broader entertainment agenda and increased the reach and appeal of the event. Besides the branding value, it illustrates how innovation can flow through a network, which catalyzes action.

$\mathrm{IZ}$ and its activities enable us to reflect on the key trajectories a food system needs to go through to reach sustainability. I emphasize below the most interesting and important lessons we may gain from IZ. An approach to enterprise development that draws on stakeholder engagement as opposed to technical learning and mentoring, within an events-based social innovation system, is elucidated. Forms of social capital or networks were animated by broader narratives and facilitative methods and opportunities. This enables me to comment on how activists and practitioners can advance a progressive agenda through a system of social labs.

\section{Reflecting on a Transitional Mechanism: Food Systems Change as a Conversation about Food}

South African policies (DAFF, 2008) advocate a participatory and institutional solution to innovation in agriculture and society (Ledger, 2016; Pereira et al., 2015) that can lead to autocatalytic change "composed of many elements already in existence, albeit reconfigured and combined with new participants, ideas, infrastructure, and technologies" (Bennet et al. 2016, p. 442). In the first Lab (May 2015), a participant commented on how the same people who were chased around the university by security forces during apartheid were now receiving free instructions at the same place. The background transition from apartheid is significant as a systemic transition, and my conclusions reflect on this systemic change as opposed to the minutiae of enterprise development.

However, what is a safe space for innovation? The $L a b$ as an open and free event conditions systemic changes as opposed to changes in farmers' organization. IZ can avoid organizational issues and conflicts as there are no members, and participation is completely open. Participants cannot draw on IZ for resources as it has none, and this avoids activities that only serve one organization. Participation is thus also risk-free. The event has benefits because actors can use the information and opportunities toward their own interests.

The free Wi-Fi and the SMS notifications create a sense of inclusion and belonging among participants but cannot bind participants to a set agenda. The fact that enterprises need to be pursued independently of IZ has deeper systemic effects and creates conditions best suited to building a class of Africa producers rather than organizing them all into a singular association. A singular association will undoubtedly narrow down production systems and possibly reify emergent producers into set production regimes. Innovation needs experimentation, which means that farmers act autonomously in realizing their interests in new ways. The innovations needed are not grand innovations but iterative changes to local food enterprises.

The Lab allows stakeholders to make such changes by planning their own engagement with stakeholders and opportunities. Actors should be able to freely mix bonding, bridging, and linking social capital to suit their interests. This is what one would expect of mature enterprises, and this must be encouraged among emerging entrepreneurs as well. They cannot all be bound by a singular technology or new production routine, which is prevalent in technology-driven agencies. The low costs of engagement allow many stakeholders who also want to empower farmers to do so without capturing them, thereby benefitting emerging entrepreneurs as opposed to powerful stakeholders.

The Lab enabled farmers to build relationships among themselves, and this bonding social capital is evident in the collaborative announcement hour that allows farmers and others to trade among themselves. This was very difficult in the past due 
to the isolated nature of townships and is important for the broader economic development of South Africa.

The way entrepreneurs built relationships among themselves drew significantly from narratives of broader political transition but added stories about permaculture, organic or imvelo (natural) farming, and local township self-reliance. Food production at this scale is indeed lucrative (Nkosi et al. 2014), and the $L a b$ has emphasized the ecological base of such viable food gardens and farms. This has created a narrative of how a township-based enterprise can survive and has led to a series of videos on the Facebook page and website on how to build a circular economy. The Lab cannot create such enterprises but can give actors the confidence to develop them by making suggestions to enterprises that trade locally and on a small scale.

The Lab has also made possible relationships beyond the immediate context by linking with local state officials, activists, and academics. Soon after implementing the Lab, I was invited to a similar workshop session by the city of Johannesburg (March 2015) using these methods. Because an open $L a b$ is not owned by anyone, anyone can use the lab to recruit farmers and entrepreneurs, and many do. The mere existence of such a lab has effects across society. Because multiple presenters are often invited, no single actor can capture the event. However, supply and value chains, which are forms of association, can be made much more transparent in this way and enable emerging entrepreneurs to trade selectively, so they benefit themselves. This governs the market.

While associations can build the synergies we need for sustainable development, they may not be able to bridge the gap between bonding and bridging and linking social capital. The forms of association needed for a transition to sustainability have to bridge this gap. IZ suggests that networks would be more important than organizations and close associations, as they narrow the scope for innovation by relying almost exclusively on bonding social capital. Bridging and linking social capital is key in innovation, particularly if technology is incorporated in enterprises. My experience suggests that the right narratives need to be employed alongside networks and stakeholders to realize this. Facilitation is needed, but the overall character of the engagement event is also pertinent. Open events allow a broader diversity of networking, and this allows actors to find the right connections, albeit by trial and error.

The Slow Food Eat-In demonstrates how to create such synergies. Slow Food International, a large, respected organization (while Slow Food South Africa is fledgling), brings a superstructure wherein members and representatives of numerous other activist organizations can participate. The layering of organizations at this event, the Free People's conferences that attracted both academics and many ordinary people from both the local area and from outside the townships, and the resulting interaction and innovation give meaning to the idea of a safe space. Underneath the broader superstructure of Slow Food's narrative of "good, clean and fair," we mobilized diverse organizations, and this avoided the parochialism of an exclusive, say, “organic" focus (Anderson \& McLachlan, 2015, p. 13).

\section{Conclusion}

IZ, the Farmers' Lab, the Slow Food Soweto Eat-In, and a series of related events enabled emergent farmers to seize opportunities in the South African political transition and move towards sustainability. To realize sustainability, networks may be more important than farmers' organizations, and interaction among stakeholders needs to be facilitated. But above all, it is the stories we tell about change that re-organize society for sustainability.

\section{References}

Anderson, C. R., \& McLachlan, S. M. (2015). Transformative research as knowledge mobilization: Transmedia, bridges, and layers. Action Research, 14(3), 295-317. https://doi.org/10.1177/1476750315616684

Battersby, J. (2011). Urban food insecurity in Cape Town, South Africa: An alternative approach to food access. Development Southern Africa, 28(4), 545-561. https://doi.org/10.1080/0376835X.2011.605572 
Bennet, E. M., Solan, M., Biggs, R., McPhearson, T., Norström, A.,V., Olsson, P., ... Xu, J. (2016). Bright spots: Seeds of a good Anthropocene. Frontiers in Ecology and Environment, 14(8), 441-448. https://doi.org/10.1002/ fee.1309

Blattner, C. E. (2020). Just transition for agriculture? A critical step in tackling climate change. Journal of Agriculture, Food Systems, and Community Development, 9(3), 53-58. https://doi.org/10.5304/jafscd.2020.093.006

Bojer, M., Roehl, H., Knuth, M., \& Magner, C. (2008). Mapping dialogue: Essential tools for change. Chagrin Falls: Taos Institute.

Brand, K. G. (2014). Design and development of a household farming kit (Master's thesis). University of Johannesburg. Retrieved from http://hdl.handle.net/10210/11035

Broad-Based Black Economic Empowerment Act No. 25899. (Act No. 53 of 2003). (2004, January 9). Retrieved from Government Gazette: https://www.gov.za/sites/default/files/gcis document/201409/a53-030.pdf

Brown, I. L. (2017). An appropriate technology system for emergent beekeepers: Field testing and development towards implementation (Master's thesis). University of Johannesburg. Retrieved from http://hdl.handle.net/10210/263178

Bundy, C. (1988). The rise and fall of the South African peasantry (2nd ed.). Cape Town: David Phillip.

Burns, D. (2012). Participatory systemic inquiry. IDS Bulletin, 43(3), 88-100. http://dx.doi.org/10.1111/j.1759-5436.2012.00325.x

Burns, D. (2014). Systemic action research: Changing system dynamics to support sustainable change. Action Research, 12(1), 3-18. https://doi.org/10.1177/1476750313513910

Campbell, A. D. (2017). Lay designers: Grassroots innovation for appropriate change. Design Issues, 33(1), 30-47. https://doi.org/10.1162/DESI a 00424

Campbell, A. D., \& Brown, I. L. (2018). A potential difference model for educating critical citizen designers: The case study of the Beegin Appropriate Beekeeping Technology System. In E. Costandius \& H. Botes (Eds.), Educating citizen designers in Southern Africa (pp. 85-104). Stellenbosch: Sun Press.

Campbell, A. D., \& Harrison, P. H. (2015). A framework for socio-technical innovation: The case of a human-powered shredder. In L. Collina, L. Galluzzo \& A. Meroni (Eds.), Proceedings of the Cumulus Conference: The virtuous circle: Design culture and experimentation (pp. 211-230). Milan: McGraw Hill.

Campbell, A. D., \& Malan, N. (2018). iZindaba Zokudla (conversations about food): Innovation in the Soweto food system. In L. M. Abendroth \& B. Bell (Eds.), Public interest design education guidebook: Curricula, strategies, and SEED academic case studies (pp. 158-164). New York: Routledge. https://doi.org/10.4324/9781315627458-19

Castells, M. (2009). The rise of the network society (Vol. 1). Oxford: Wiley-Blackwell.

Codes of Good Practice on Broad Based Black Economic Empowerment No. 1354. (2017, December 8). Retrieved from Government Gazette: https://www.gov.za/sites/default/files/gcis document/201712/41306gon1354.pdf

Coenen, L., Benneworth, P., \& Truffer, B. (2012). Towards a spatial perspective on sustainability transitions. Research Policy, 41(6), 968-979. https://doi.org/10.1016/j.respol.2012.02.014

Cochet, H., Anseeuw, W., \& Fréguin-Gresh, S. (2015). South Africa's agrarian question. Pretoria: HSRC Press.

Crush, J. S., \& Frayne, G. B. (2011). Urban food insecurity and the new international food security agenda. Development Southern Africa, 28(4), 527-544. http://dx.doi.org/10.1080/0376835X.2011.605571

Csortan, G., Ward, J., \& Roetman, P. (2020). Productivity, resource efficiency and financial savings: An investigation of the current capabilities and potential of South Australian home food gardens. PLoS ONE, 15(4), e0230232. https://doi.org/10.1371/journal.pone.0230232

Department of Agriculture, Forestry and Fisheries of the Republic of South Africa [DAFF]. (2008). National agricultural research and development strategy. Pretoria: Government Printers. Retrieved from https://www.gov.za/documents/national-agricultural-research-and-development-strategy

Diekmann, L. O., Gray, L. C., \& Baker, G. A. (2018). Growing 'good food': Urban gardens, culturally acceptable produce and food security. Renewable Agriculture and Food Systems, 35(2), 169-181. https://doi.org/10.1017/S1742170518000388

Dubbelling, M. (2010). Cities, poverty and food: Multi-stakeholder policy and planning in urban agriculture. Rugby: Practical Action Publishing. https://doi.org/10.3362/9781780440545 
Dutilleul, B., Birrer, F. A. J., \& Mensink, W. (2010). Unpacking European living labs: Analysing innovation’s social dimensions. Central European Journal of Public Policy, 4(1), 60-85.

Frayne, B., Crush, J., \& McLachlan, M. (2014). Urbanization, nutrition and development in Southern African cities. Food Security, 6, 101-112. https://doi.org/10.1007/s12571-013-0325-1

Frayne, B., McCordic, C., \& Shilomboleni, H. (2014). Growing out of poverty: Does urban agriculture contribute to household food security in Southern African cities? Urban Forum, 25(2), 177-189. https://doi.org/10.1007/s12132-014-9219-3

Friedmann, H., \& McMichael, P. (1989). Agriculture and the state system: The rise and decline of national agricultures, 1970 to present. Sociologia Ruralis, 29(2), 93-117.

Frison, E. A. (2016). From uniformity to diversity: A paradigm shift from industrial agriculture to diversified agroecological systems. Report of the International Panel of Experts on Sustainable Food systems [IPES-Food]. Retrieved from https://cgspace.coiar.org/handle/10568/75659

Garud, R., \& Gehman, J. (2012). Metatheoretical perspectives on sustainability journeys: Evolutionary, relational and durational. Research Policy, 41(6), 980-995. https://doi.org/10.1016/j.respol.2011.07.009

Geels, F. W., \& Schot, J. (2007). Typology of sociotechnical transition pathways. Research Policy, 36(3), $399-417$. https://doi.org/10.1016/i.respol.2007.01.003

Greenberg, S. (2010). Contesting the food system in South Africa: Issues and opportunities (Research Report No. 42). Institute for Poverty, Land and Agrarian Studies, University of the Western Cape. http://hdl.handle.net/10566/572

Hammelman, C., Levkoe, C. Z., Agyeman, J., Kharod, S., Moragues Faus, A., Munoz, E., .. . Wilson, A. (2020). Integrated food systems governance: Scaling equitable and transformative food initiatives through scholar-activist engagement. Journal of Agriculture, Food Systems, and Community Development, 9(2), 71-86. https://doi.org/10.5304/jafscd.2020.092.003

Hassan, Z. (2014a). The social labs revolution: A new approach to solving our most complex challenges. San Francisco: BerrettKoehler Publishers.

Hassan, Z. (2014b). Towards a theory of systemic action. Retrieved from https://static1.squarespace.com/static/5eea166df25ed350848d72ce/t/5ef4d22bf159c74e4e325df2/1593102892366 LTowards a Theory Of Systemic Action REV03.pdf

Herbel, D., \& Haddad, N. O. (2012). Successful farmer collective action to integrate food production into value chains. Food Chain, 2(2), 164-182. https://doi.org/10.3362/2046-1887.2012.015

Jørgensen, U. (2012). Mapping and navigating transitions-The multi-level perspective compared with arenas of development. Research Policy, 41(6), 996-1010. https://doi.org/10.1016/j.respol.2012.03.001

Kahane, A. (2010). Power and love: A theory and practice of social change. San Francisco: Brett-Koehler Publishers.

Latour, B. (2007). Reassembling the social: An introduction to actor-network-theory. Oxford: Oxford University Press.

Ledger, T. (2016). An empty plate: Why we are losing the battle for our food system, why it matters, and how we can win it back. Johannesburg: Jacana Media.

Lenton, T. M., \& Latour, B. (2018). Gaia 2.0.: Could humans add some level of self-awareness to Earth's self-regulation? Science, 361(6407), 1066-1068. https://doi.org/10.1126/science.aau0427

Lynde, R. (2020). Innovation \& entrepreneurship driving food system transformation. Physiology \& Behavior, 220(1), 112866. https://doi.org/10.1016/j.physbeh.2020.112866

Mahajan, S. (2014). Economics of South African townships: Special focus on Diepsloot. World Bank Studies. Washington, D.C.: World Bank. https://doi.org/10.1596/978-1-4648-0301-7

Malan, N. (2015). Design and social innovation for systemic change: Creating social capital for a farmers' market. In L. Collina, L. Galluzzo, \& A. Meroni (Eds.), The virtuous circle: Design culture and experimentation (pp. 965-978). Milan: McGraw-Hill Education.

Malan, N. (2020a). Service learning and stakeholder action: Technology and education for urban agriculture in Johannesburg, South Africa. In A. Thornton (Ed.), Urban Food Transitions in the Global North \& South (pp. 177-192). Palgrave Macmillan. https://doi.org/10.1007/978-3-030-17187-2 11

Malan, N. (2020b). Emerging enterprises and sustainability in the food system: Food entrepreneurs in South Africa. In A. Thornton (Ed.), Urban Food Transitions in the Global North \& South (pp. 193-212). Palgrave Macmillan. https://doi.org/10.1007/978-3-030-17187-2 12 
Malan, N., \& Campbell, A. D. (2014). Design, social change and development: A social methodology. In A. Breytenbach \& K. Pope (Eds.), Design with the Other 90\%: Changing the World by Design (pp. 94-101). Johannesburg: Greenside Design Center \& University of Johannesburg. Retrieved from https://www.cumulusassociation.org/design-with-the-other-90-cumulus-johannesburg-conference-proceedings/

Malan, N., \& van der Walt, J. (2019). Building digital and real communities for change: The design of iZindaba Zokudla groups. https://doi.org/10.13140/RG.2.2.13983.51367

Manzini, E. (2014). Design, when everybody designs: An introduction to design for social innovation. Cambridge, MA: MIT Press.

McGann, M., Blomkamp, E., \& Lewis, J. M. (2018). The rise of public sector innovation labs: Experiments in design thinking for policy. Policy Sciences, 51, 249-267. https://doi.org/10.1007/s11077-018-9315-7

McGann, M., Wells, T., \& Blomkamp, E. (2019). Innovation labs and co-production in public problem solving. Public Management Review. https://doi.org/10.1080/14719037.2019.1699946

McIntyre, B. D., Herren, H. R., Wakhungu, J., \& Watson, R. T. (2009). International assessment of agricultural knowledge, science and technology for development (LAASTD): Synthesis report. Washington, D.C.: Island Press.

McMichael, P. (2005). Global development and the corporate food regime. In F. H. Buttel \& P. McMichael (Eds.), New Directions in the Sociology of Global Development (Vol. 11) (pp. 265-299). Emerald Group Publishing. https://doi.org/10.1016/S1057-1922(05)11010-5

McMichael, P. (2009). A food regime genealogy. Journal of Peasant Studies, 36(1), 139-169. https://doi.org/10.1080/03066150902820354

National Academies of Sciences, Engineering, and Medicine [NASEM]. (2018). Science breakthroughs to advance food and agricultural research by 2030. Washington, D.C.: The National Academies Press. https://doi.org/10.17226/25059

Neves, D., \& Du Toit, A. (2014). The government of poverty and the arts of survival: Mobile and recombinant strategies at the margins of the South African economy. The Journal of Peasant Studies, 41(5), 833-853.

https://doi.org/10.1080/03066150.2014.894910

Nkosi, S., Gumbo, T., Kroll, F., \& Rudolph, M. (2014). Community gardens as a form of urban household food and income supplements in African cities: Experiences in Hammanskraal, Pretoria (AISA Policy brief No. 112).

Nogueira, A., Ashton, W., Teixeira, C., Lyon, E., \& Pereira, J. (2020). Infrastructuring the circular economy. Energies, 13(7), 1805. https://doi.org/10.3390/en13071805

Pereira, L., \& Drimie, S. (2016). Governance arrangements for the future food system: Addressing complexity in South Africa. Environment: Science and Policy for Sustainable Development, 58(4), 18-31. https://doi.org/10.1080/00139157.2016.1186438

Pereira, L. M., Drimie, S., Maciejewski, K., Tonissen, P. B., \& Biggs, R. (2020). Food System Transformation: Integrating a Political-Economy and Social-Ecological Approach to Regime Shifts. International Journal of Environmental Research and Public Health, 17(4), 1313. https://doi.org/10.3390/ijerph17041313

Pereira, L., Karpouzoglou, T., Doshi, S., \& Frantzeskaki, N. (2015). Organising a safe space for navigating socialecological transformations to sustainability. International Journal of Environmental Research and Public Health, 12(6), 60276044. https://doi.org/10.3390/ijerph120606027

Regeer, B., Mager, S., \& van Oorsouw, Y. (2011). License to grow: Innovating sustainable development by connecting values: An insight in the connected value development approach for wicked problems. Amsterdam: Vrije Universiteit Press.

REOS Partners \& TransForum. (2011). Summit Report: $1^{\text {st }}$ Global Summit on Metropolitan Agriculture. Retrieved from https://Reospartners.com/wp-content/uploads/old/SummitReport 17012011.pdf

Rousell, C. (2017). Seed capture in South Africa: A threat to seed freedom but the seed movement is fighting back. Retrieved from African Centre for Biodiversity website: https://acbio.org.za/en/seed-capture-south-africa-threat-seed-freedom-seed-movement-fighting-back

Ruysenaar, S. (2013). Reconsidering the 'Letsema Principle' and the role of community gardens in food security: Evidence from Gauteng, South Africa. Urban Forum, 24, 219-249. https://doi.org/10.1007/s12132-012-9158-9

Slow Food. (2018, July 9). New slow food presidia: South African rainbow maize and rex union orange. Retrieved from https://www.slowfood.com/presidia-south-africa-rainbow-maize-rex-union-orange/ 
Southern Africa Food Lab [SAFL] \& Reos Partners South Africa. (2015). The future of food in South Africa: Four scenarios examining possible futures of the food system in South Africa. Stellenbosch: The Southern Africa Food Lab.

Stewart, R., Korth, M., Langer, L., Rafferty, S., Rebelo Da Silva, N., \& van Rooyen, C. (2013). What are the impacts of urban agriculture programs on food security in low and middle-income countries? Environmental Evidence, 2(7). https://doi.org/10.1186/2047-2382-2-7

The Economist. (2015, February 28). I had a farm in Africa: South Africa takes a populist turn on land reform. Retrieved from http://www.economist.com/news/middle-east-and-africa/21645232-south-africa-takes-populist-turn-landreform-i-had-farm-africa

Tobias, J. M., Mair, J., \& Barbosa-Leiker, C. (2013) Toward a theory of transformative entrepreneuring: Poverty reduction and conflict resolution in Rwanda's entrepreneurial coffee sector. Journal of Business Venturing, 28(6), 728 742. https://doi.org/10.1016/i.jbusvent.2013.03.003

Triomphe, B., Floquet, A., Waters-Bayer, A., Kamau, G., van den Berg, J., Letty, B., . . Oudwater, N. (2014). Multistakeholder innovation processes in African smallholder farming: Key lessons and policy recommendations from Benin, Kenya and South Africa. In B. Triomphe, A. Waters-Bayer, L. Klerkx, M. Schut, B. Cullen, G. Kamau, \& E. Le Borgne (Eds.), Innovation in smallholder farming in Africa: Recent advances and recommendations (Proceedings of the International Workshop on Agricultural Innovation Systems in Africa [AISA], 29-31 May 2013, Nairobi, Kenya) (pp. 44-55). Montpellier, France: Centre for International Cooperation in Agricultural Research for Development (CIRAD). Retrieved from https://cgspace.cgiar.org/handle/10568/35193

UN Habitat. (2008). How to set up and manage a town-level multi-stakeholder forum: A step-by-step guide. Nairobi: UN Habitat.

Van Latesteijn, H., \& Andeweg, K. (2011). The TransForum model: Transforming agro-innovation towards sustainable development. Dordrecht: Springer. https://doi.org/10.1007/978-90-481-9781-1

van $\mathrm{Zyl}$, C. (2014). The challenges and complexities inherent to multidisciplinary community engagement projects in service learning. In A. Breytenbach \& K. Pope (Eds.), Design with the Other 90\%: Changing the World by Design (pp. 351-358). Johannesburg: Greenside Design Center \& the University of Johannesburg. Retrieved from https://www.cumulusassociation.org/design-with-the-other-90-cumulus-johannesburg-conference-proceedings/

Yin, R. K. (2009). Case study research: Design and methods (4th Ed.). Los Angeles: SAGE.

Zezza, A., \& Tasciotti, L. (2010). Urban agriculture, poverty, and food security: Empirical evidence from a sample of developing countries. Food Policy, 35(4), 265-273. https://doi.org/10.1016/i.foodpol.2010.04.007 